\title{
Pukala intrusion, its age and connection to hydrothermal alteration in Orivesi, southwestern Finland.
}

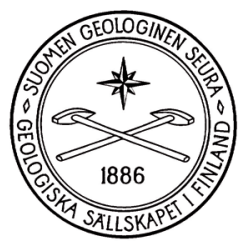

\author{
Matti TAlikKa AND Irmeli MäNTtäRI \\ Geological Survey of Finland, P.O. Box 96, FI-02151 Espoo, Finland
}

\begin{abstract}
The Pukala intrusion is situated in the Paleoproterozoic Svecofennian domain of the Fennoscandian Shield in the contact region between the Central Finland Granitoid Complex and the Tampere Belt. The acid subvolcanic intrusion, which is in contact or close to several altered domains, mainly consists of porphyritic granodiorite and trondhjemite. The Pukala intrusion was emplaced into volcanic sequence in an island-arc or fore-arc setting before or during the early stages of the main regional deformation phase of the Svecofennian orogeny. On the basis of the geochemical data, the Pukala intrusion is a peraluminous volcanic-arc granitoid. After crystallisation at 1896 \pm 3 Ma, multiphase deformation and metamorphism caused alteration, recrystallisation, and orientation of the minerals, and tilted the intrusion steeply towards south. The $|85| \pm 5 \mathrm{Ma} U-\mathrm{Pb}$ age for titanite is connected to the late stages of the Svecofennian tectonometamorphic evolution of the region.

Several hydrothermally altered domains are located in the felsic and intermediate metavolcanic rocks of the Tampere Belt within less than one kilometre south of the Pukala intrusion. Alteration is divided into three basic types: partial silica alteration, chloritesericite \pm silica alteration, and sericite alteration in shear zones. The first two types probably formed during the emplacement and crystallisation of the Pukala intrusion, and the third is linked to late shearing. Intense sericitisation and comb quartz bands in the contact of the intrusion and the altered domain at Kutemajärvi suggest that the hydrothermal system was driven by the Pukala intrusion.
\end{abstract}

Keywords: intrusions, granodiorites, trondhjemite, geochemistry, Svecofennian orogeny, hydrothermal alteration, absolute age, U/Pb, Paleoproterozoic, Pukala, Kutemajärvi, Orivesi, Finland

* Corresponding author email: matti.talikka@gtk.fi 


\section{Introduction}

In orogenic belts, hypabyssal intrusions form from residual of liquids in magma chambers of volcanoes or crystallise from magma chambers that did not erupt. The intrusions often create hydrothermal systems that may carry constituents to and cause mineralisation in the intrusions and their country rocks. For example, epithermal gold \pm telluride \pm silver deposits form as a result of hydrothermal activity during a period of volcanism and/or magmatism at subvolcanic depths (Heald et al., 1987; Hedenquist et al., 1996).

The study area, located in a Paleoproterozoic orogenic belt, contains a subvolcanic intrusion, volcanic rocks of island arc type, and a metamorphosed epithermal gold deposit (Seitsaari, 1951; Laitakari, 1986; Kähkönen, 1989; Kähkönen et al., 1989; Luukkonen et al., 1992; Kojonen et al., 1999; Talikka, 2003; FINGOLD database, www.gtk.fi/explor/, 20.2.2005). The purpose of this paper is to provide information of the relation between the subvolcanic intrusion and altered domains from the area inves- tigated by presenting petrological, geochemical, and age data on the Pukala intrusion. With emphasis on the Kutemajärvi area, we also discuss the tectonometamorphic history of the area studied.

\section{Geologic setting}

The study area is in Orivesi, southwestern Finland, in the centre of the Svecofennian domain, which formed 1920-1870 Ma ago as a result of accretion of several island-arcs and microcontinents against the Archaean craton (Lahtinen et al., 2005). Several separate, in places concurrent, collisions took place producing a number of orogenic events and extensional phases between them (Lahtinen et al., 2005). The Svecofennian domain is divided in three main regions: the primitive arc complex, the arc complex of western Finland, and the arc complex of southern Finland (Korsman et al., 1997). The study area is located in the southern part of the arc complex of western Finland (Fig. 1).

The Svecofennian domain is predominantly composed of Paleoproterozoic metasedimentary rocks,

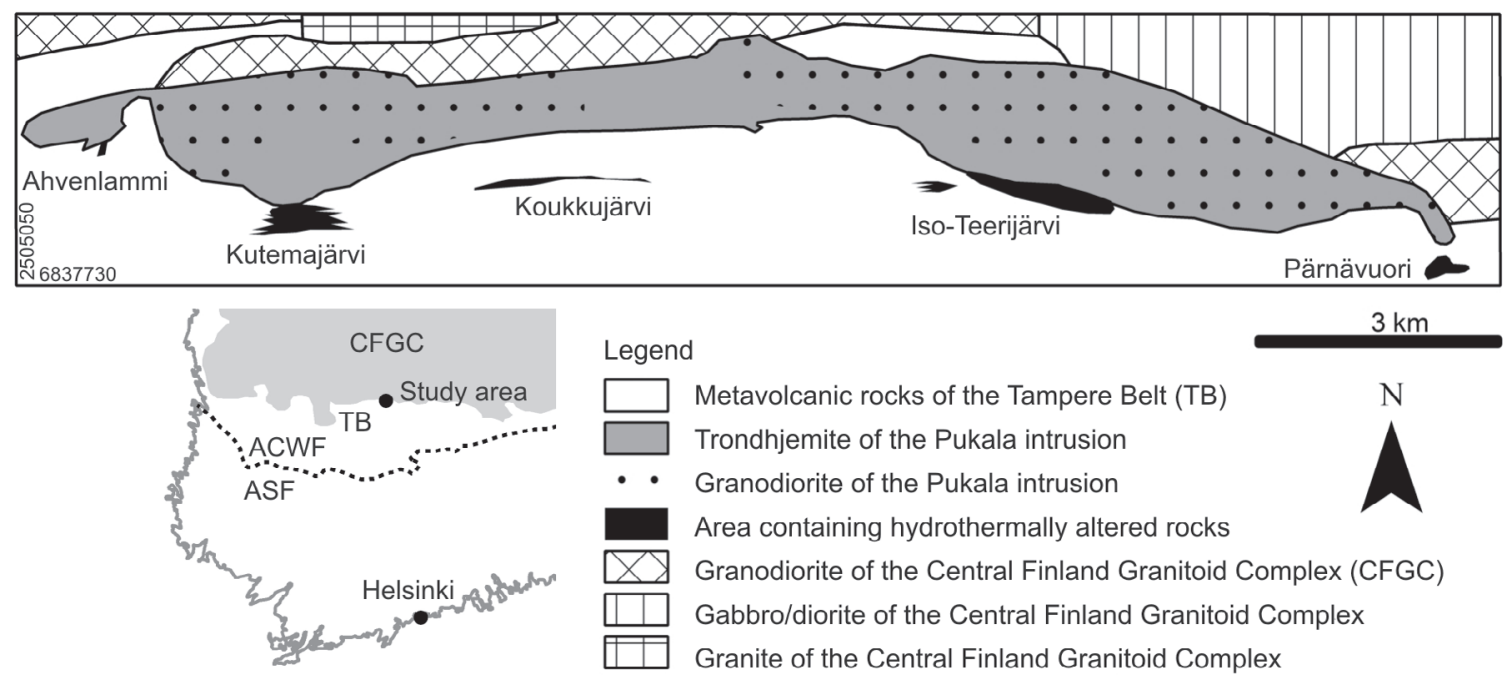

Fig I. Generalised geological map of the study area.The Pukala intrusion is located in Orivesi, southwestern Finland, in the contact region between the Central Finland Granitoid Complex (CFGC) and the Tampere Belt (TB). Several small hydrothermally altered domains are situated in the metavolcanic rocks immediately to the south of the Pukala intrusion. ASF = arc complex of southern Finland, ACWF = arc complex of central and western Finland. Modified from Seitsaari (195I), Laitakari (1986), and Talikka (2003). Inset after Korsman et al. (I997). 
metavolcanic rocks of island-arc type, and granitoids, which have intruded into the supracrustal rocks (Gaál \& Gorbatschev, 1987; Korsman et al., 1997; Nironen, 1997; Kilpeläinen, 1998). The sedimentary and volcanic rocks were metamorphosed under hightemperature and low-pressure conditions (Korsman, 1977; Korsman et al., 1984; Schreurs, 1984; Schreurs \& Westra, 1985; Hölttä, 1986; Kilpeläinen, 1998). The supracrustal rocks are mostly 2000-1880 Ma and the I-type granitoids 1890-1880 Ma old (Nurmi et al., 1984; Huhma, 1986; Kähkönen et al., 1989; Nironen, 1989; Kilpeläinen, 1998).

The Pukala intrusion lies between the Central Finland Granitoid Complex (CFGC) and the Tampere Belt (TB; Nironen et al., 2002) (Fig. 1). The country rocks on the northern side of the intrusion comprise granite, granodiorite, and gabbro of the CFGC. The northern edge of the Pukala intrusion follows a chain of lakes, which may indicate a presence of a shear zone along the contact between the CFGC and the Pukala intrusion. To the south of the intrusion, there are intermediate metavolcanic rocks of the $\mathrm{TB}$ with some felsic and mafic strata. The zircon $\mathrm{U}-\mathrm{Pb}$ ages of the metavolcanic rocks in the TB are 1904-1889 Ma (Kähkönen et al., 1989). The structure of the TB is a large synform whose northern limb mainly comprises metavolcanic rocks and the southern limb metasedimentary rocks. Several large east-west striking fault zones cut the TB (Kähkönen, 1989). In the area mapped in the present study, the strike of the main schistosity is in east-west direction and the dip is 70 $90^{\circ}$, more commonly to north than south.

\section{Pukala intrusion}

\section{I. General aspects}

The east-west striking Pukala intrusion is roughly 20 $\mathrm{km}$ long and 1-2 km wide. The intrusion consists of porphyritic granodiorite and trondhjemite (Fig. 2a-c) with minor granitic, tonalitic, and aplitic parts. The contacts between the rock types are gradual. The orientation of the weak foliation observed within the intrusion is the same as the orientation of the main regional schistosity in the metavolcanic rocks.
A number of mafic and intermediate rock enclaves are found within the intrusion, particularly in its southwestern part (Fig. 2b-c). These most likely are xenoliths from the adjoining metavolcanic rocks. The shape of the inclusions varies from oval to ragged, and their size is commonly $10-30 \mathrm{~cm}$, although inclusions up to several meters in length exist. The inclusions are oriented in east-west direction, but the mineral grains in them lack an orientation.

Two mafic dyke swarms cut through the study area. East-west striking metamorphosed dykes are commonly uralite-phyric and their paleomagnetic age is Svecofennian (Pesonen \& Neuvonen, 1981). Unmetamorphosed 1650-1600 Ma diabases strike N $50^{\circ} \mathrm{W}$ (Laitakari, 1987).

\subsection{Petrology}

All the rock types of the Pukala intrusion are porphyritic. In the granodiorite and trondhjemite, the plagioclase and potassium feldspar phenocrysts are 1-5 $\mathrm{mm}$ in diameter and commonly sericitised and saussuritised (Fig. 2a). Quartz phenocrysts (Ø 2-5 mm), of which some are recrystallised, also exist in places. The granodiorite has more phenocrysts than the trondhjemite. The fine-grained (grain size 0.01-0.2 $\mathrm{mm}$ ) matrix is predominantly quartz with some plagioclase and biotite. The only abundant mafic mineral is biotite (3-8 vol. \%), which defines the foliation. The modal compositions of the two main rock types are shown in Table 1 and in Fig. 3a. Accessory minerals include chlorite, muscovite, epidote, fluorite, apatite, carbonate, titanite, allanite, and zircon.

The intrusion is heterogeneous, with the tonalitic and granitic parts intimately intermingled. Aplite is found at few locations near the southern margin of the intrusion. In the contact of the intrusion and the outer rim of the altered domain at Kutemajärvi, comb quartz bands are present in the aplite.

Two types of rock inclusions have been identified: mafic, hornblende-biotite bearing and intermediate, biotite bearing. Both types are fine-grained and porphyritic in places. The plagioclase and/or hornblende phenocrysts are under $5 \mathrm{~mm}$ in diameter. 

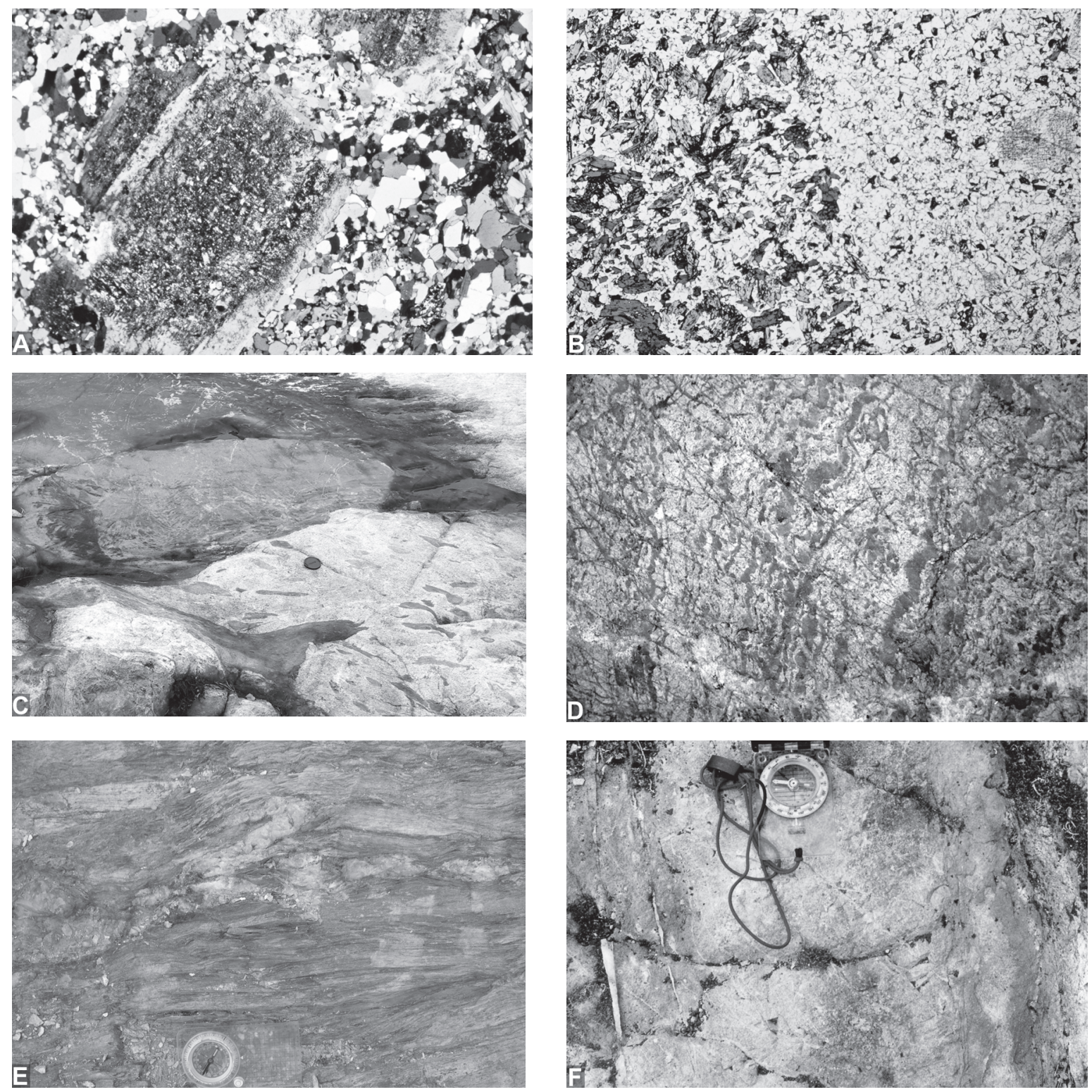

Fig. 2. a) Trondhjemite of the Pukala intrusion. Sericitised and saussuritised plagioclase phenocryst in fine-grained matrix comprising mainly quartz and biotite. The width of the view corresponds $5 \mathrm{~mm}$. b) Contact of amphibole bearing xenolith and trondhjemite (Pukala intrusion). The width of the view corresponds $5 \mathrm{~mm}$. c) Xenoliths in trondhjemite (Pukala intrusion). The diameter of the lens cap is $7.5 \mathrm{~cm}$ d) Comb quartz bands at Kutemajärvi. The width of the view corresponds $15 \mathrm{~cm}$. Photo by Aulis Kinnunen. e) Chlorite-sericite schist few tens of meters south of the Pukala intrusion at Kutemajärvi. The diameter of the compass wheel is $6 \mathrm{~cm}$. f) Partially silicified metavolcanic rock at Pärnävuori. A narrow sericitised shear on the right side.

\subsection{Chemical composition}

On the basis of their chemical composition, samples from the Pukala intrusion can be divided into two groups that correlate with the petrographic and field observations. The analytical methods and the geochemical data are presented in Table 2. The high $\mathrm{SiO}_{2}$ and $\mathrm{Na}_{2} \mathrm{O}$ contents are distinct. All rock samples are peraluminous with aluminium saturation index (ASI) values greater than 1.0 (Table 2$)$. In the $\left(\mathrm{FeO}_{\mathrm{t}} / \mathrm{MgO}\right)$ - 
Table I. Modal composition of the Pukala intrusion.

\begin{tabular}{lll}
\hline & $\begin{array}{l}\text { GRDR, N=3 } \\
\text { average (\%) }\end{array}$ & $\begin{array}{l}\text { TR, N=3 } \\
\text { average (\%) }\end{array}$ \\
\hline quartz & 43.2 & 59.6 \\
plagioclase & 24.8 & 31.9 \\
alkali-feldspar & 21.8 & 0.2 \\
biotite & 7.2 & 5.0 \\
chlorite & 0.8 & 1.7 \\
hornblende & 0.1 & $\mathrm{x}$ \\
muscovite & 1.1 & 1.0 \\
epidote, clinozoisite & 0.6 & 0.2 \\
fluorite & $\mathrm{x}$ & 0.0 \\
apatite & 0.2 & 0.1 \\
carbonate & 0.3 & 0.1 \\
titanite & $\mathrm{x}$ & 0.0 \\
allanite & $\mathrm{x}$ & 0.0 \\
zircon & $\mathrm{x}$ & $\mathrm{x}$ \\
opaques & 0.3 & 0.2 \\
\hline
\end{tabular}

Point-counting method, 1000 points/sample $\mathrm{x}=$ mineral present in thin sections $\mathrm{GRDR}=$ granodiorite, $\mathrm{TR}=$ trondhjemite Alteration to sericite/saussurite is ignored

$(\mathrm{Zr}+\mathrm{Ce}+\mathrm{Nb}+\mathrm{Y})$ plot (Fig. 3b), the granodiorite represents fractionated and the trondhjemite unfractionated melts (Whalen et al., 1987). On the basis of the Nb-Y (Fig. 3c) and the Rb-(Nb+Y) (Fig. 3e) plots, the Pukala intrusion falls into the field of volcanic arc granites as defined by Pearce et al. (1984). In the R2-R1 plot (Fig. $3 \mathrm{~d}$ ), the granodiorite and some of the analysed trondhjemites fall in the syn-collision field; some trondhjemites, however, show the characteristics of mantle fractionates (Batchelor \& Bowden, 1985).

The Pukala intrusion has been subjected to hydrothermal activity and metamorphism, which have caused changes to its chemical composition. The effects of the hydrothermal activity are seen in the varying contents of mobile elements such as barium, potassium, and silica. The contents of immobile elements, e.g., aluminium, zirconium, and titanium, vary only slightly within the intrusion.

When compared with the synkinematic (Lahtinen, unpublished data) and the postkinematic granitoids (Nironen et al., 2000) of the CFGC, and the rapakivi granites of Finland (Vorma, 1976; Rämö, 1991), the Pukala intrusion does not correlate well with any of these granitoid types (Table 3). The closest relation is seen with the synkinematic granitoids in the Ba-Rb-Sr plot (Fig. 3f) and with syn- and postkinematic granitoids of the CFGC in the $\mathrm{Rb}-(\mathrm{Nb}+\mathrm{Y})$ diagram (Fig. 3e).

\subsection{Age}

For U-Pb age dating, zircon and titanite were separated from a granodiorite sample (A1675) of the Pukala intrusion. The U-Pb analytical data and methods are presented in Table 4. A total of five zircon fractions comprising yellowish to brownish, transparent, prismatic (1:w - 2-4) zircons were analysed. Despite the different abrasion times and grain-size fractions, the data practically forms a three point discordia line. It intercepts the concordia curve at $1896 \pm 3 \mathrm{Ma}$ and $193 \pm 29 \mathrm{Ma}(\mathrm{MSWD}=1.3 ; \mathrm{n}=5$ ) (Fig. 4).

The titanite fraction E\#1 gave a slightly discordant age result with ${ }^{207} \mathrm{~Pb} /{ }^{206} \mathrm{~Pb}$ age of $1849 \pm 5 \mathrm{Ma}$ (Table 4). The concordia age for the other titanite fraction (E\#2) is $1851 \pm 5 \mathrm{Ma}$ (Fig. 4). Consequently, both sphene fractions are coeval.

The emplacement age of the Pukala intrusion is $1896 \pm 3 \mathrm{Ma}$. The clearly younger age of $1851 \pm 5 \mathrm{Ma}$ for the titanite may imply local cooling under -500 ${ }^{\circ} \mathrm{C}$ after intrusion and metamorphic events. The peak metamorphism in the Svecofennian Tonalite-Trondhjemite Migmatite Belt occurred at ca. $1880 \mathrm{Ma}$ (Mouri et al., 1999). According to Nironen (1989), the uraninite $\mathrm{U}-\mathrm{Pb}$ age of $\mathrm{ca}$. $1.86 \mathrm{Ga}$ from a tourmaline breccia of the Ylöjärvi $\mathrm{Cu}-\mathrm{W}$ deposit, $35 \mathrm{~km}$ to the west of the Pukala intrusion, dates local $\mathrm{D}_{2}$ deformation and represents a retrogressive tectonothermal stage. Furthermore, the whole rock $\mathrm{Rb}-\mathrm{Sr}$ isochron age of $1847 \pm 92 \mathrm{Ma}$ (Kähkönen et al., 1989), although with large errors, may reflect the waning stages of the Svecofennian tectonothermal activity.

\subsection{Depth of crystallisation}

According to our interpretation, the Pukala intrusion was emplaced as a sheet-like intrusion between the volcanic strata at $1896 \mathrm{Ma}$ and tilted gently to the 

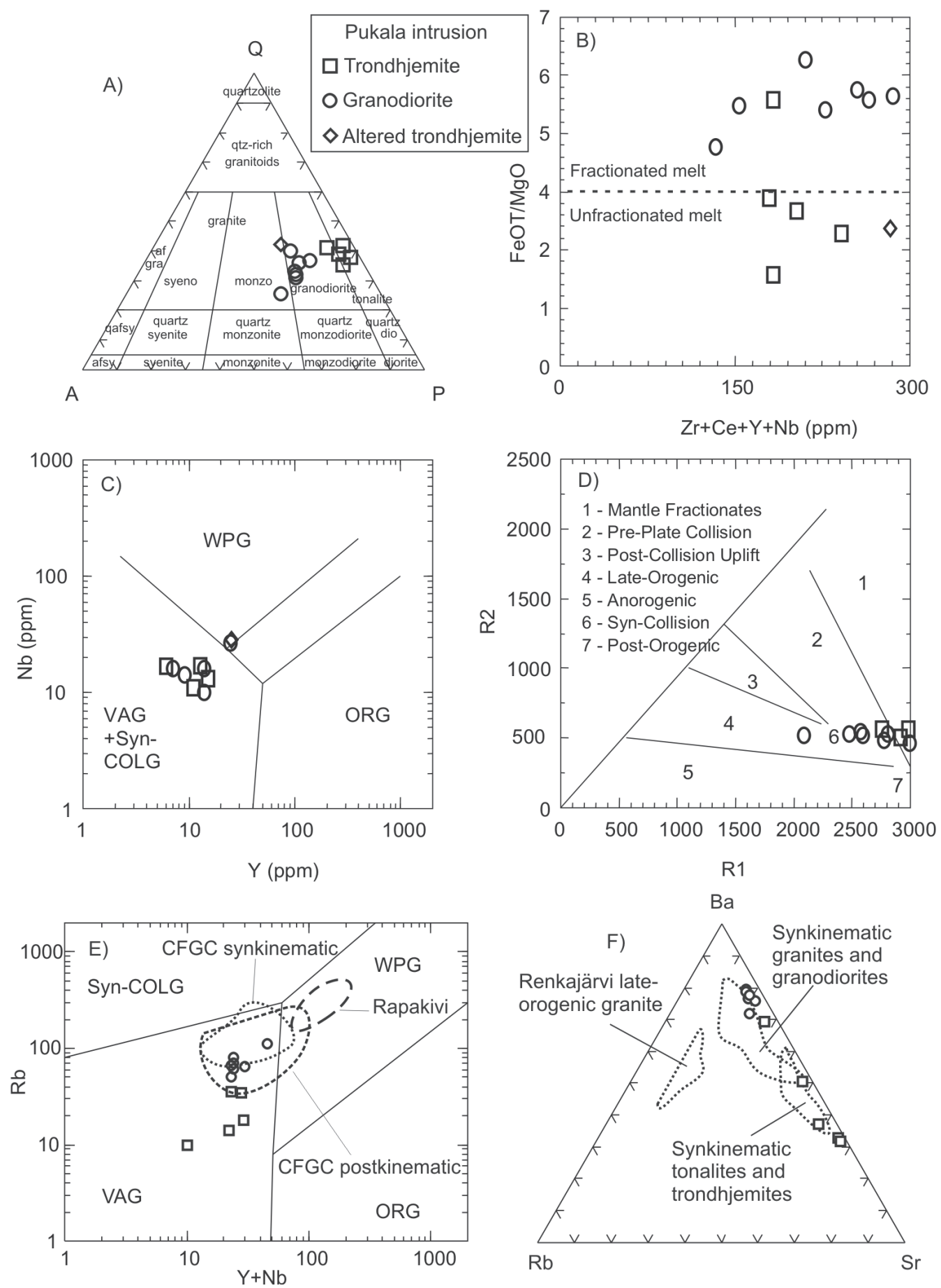

Fig. 3. a) Modal composition of the Pukala intrusion plotted in the QAP diagram introduced by Streckeisen (I974). b) $(\mathrm{FeOt} / \mathrm{MgO})$ vs. $(\mathrm{Zr}+\mathrm{Nb}+\mathrm{Ce}+\mathrm{Y})$ plot after Whalen et al. (1987). c) Nb vs. Y plot by Pearce et al. (I984). VAG = volcanic arc granite, Syn-COLG = syn-collisional granites, WPG = within plate granites, ORG = ocean ridge granites. d) R2 vs. RI plot by Batchelor and Bowden (I985). $\mathrm{RI}=4 \mathrm{Si}-\mathrm{I} \mathrm{I}(\mathrm{Na}+\mathrm{K})-2(\mathrm{Fe}+\mathrm{Ti}), \mathrm{R} 2=6 \mathrm{Ca}+2 \mathrm{Mg}+\mathrm{Al}$. e) $\mathrm{Rb}$ vs. $(\mathrm{Nb}+\mathrm{Y}$ ) plot by Pearce et al. (1984). CFGC synkinematic and CFGC postkinematic, type I (Nironen et al., 2000), rapakivi (Vorma, 1976; Rämö, I99l) f) Ba-Rb-Sr diagram. Synkinematic granitoids (Nurmi et al., 1984), Renkajärvi late-orogenic granite (unpublished data; Nurmi \& Haapala, 1986). 
Table 2. Geochemical data on the Pukala intrusion.

\begin{tabular}{|c|c|c|c|c|c|c|c|c|c|c|c|c|c|}
\hline Sample & $120 \mathrm{~A}$ & 163 & 31 & 349 & 143 & 153 & 220 & 229 & 244 & $36 \mathrm{~A}$ & 355 & 391 & 409 \\
\hline Rock type & TR & TR & TR & TR & GRDR & GRDR & GRDR & GRDR & GRDR & GRDR & TR & GRDR & $\mathrm{TR}$ \\
\hline X-coord & 6839255 & 6839750 & 6839440 & 6840130 & 6840270 & 6839830 & 6839556 & 6839365 & 6839157 & 6839790 & 6840432 & 6840180 & 6839732 \\
\hline Y-coord & 2517630 & 2514019 & 2505960 & 2513487 & 2516850 & 2515770 & 2519420 & 2519186 & 2521511 & 2510920 & 2512742 & 2508860 & 2512707 \\
\hline $\mathrm{SiO}_{2}$ & 73.00 & 74.10 & 76.70 & 76.41 & 69.50 & 72.40 & 73.31 & 71.98 & 75.09 & 74.20 & 75.64 & 72.00 & 75.33 \\
\hline $\mathrm{TiO}_{2}$ & 0.23 & 0.21 & 0.12 & 0.18 & 0.27 & 0.21 & 0.21 & 0.25 & 0.19 & 0.18 & 0.17 & 0.19 & 0.23 \\
\hline $\mathrm{Al}_{2} \mathrm{O}_{3}$ & 14.80 & 14.30 & 13.10 & 13.30 & 15.70 & 14.60 & 13.70 & 14.30 & 12.90 & 14.20 & 13.80 & 15.00 & 13.00 \\
\hline $\mathrm{FeOt}$ & 2.50 & 2.25 & 1.38 & 1.31 & 3.03 & 2.40 & 2.27 & 2.57 & 2.16 & 1.98 & 1.03 & 2.19 & 2.16 \\
\hline $\mathrm{MnO}$ & 0.07 & 0.06 & 0.04 & 0.03 & 0.07 & 0.06 & 0.07 & 0.08 & 0.06 & 0.04 & 0.02 & 0.05 & 0.05 \\
\hline $\mathrm{MgO}$ & 0.47 & 0.67 & 0.50 & 0.42 & 0.56 & 0.39 & 0.41 & 0.48 & 0.42 & 0.45 & 0.56 & 0.42 & 0.81 \\
\hline $\mathrm{CaO}$ & 2.38 & 2.32 & 0.92 & 2.43 & 1.77 & 2.05 & 2.26 & 2.29 & 1.84 & 1.69 & 1.90 & 2.04 & 1.72 \\
\hline $\mathrm{Na}_{2} \mathrm{O}$ & 5.08 & 4.73 & 3.57 & 4.83 & 3.94 & 3.87 & 3.72 & 3.80 & 3.47 & 4.35 & 5.59 & 4.04 & 4.59 \\
\hline $\mathrm{K}_{2} \mathrm{O}$ & 0.97 & 0.88 & 3.31 & 0.49 & 4.50 & 3.36 & 2.93 & 3.38 & 3.05 & 2.40 & 0.42 & 3.51 & 1.25 \\
\hline $\mathrm{P}_{2} \mathrm{O}_{5}$ & 0.09 & 0.07 & 0.02 & 0.04 & 0.11 & 0.07 & 0.05 & 0.07 & 0.05 & 0.06 & 0.04 & 0.07 & 0.07 \\
\hline Total & 99.59 & 99.59 & 99.66 & 99.44 & 99.45 & 99.41 & 98.93 & 99.20 & 99.23 & 99.55 & 99.17 & 99.51 & 99.21 \\
\hline$\overline{\mathrm{Rb}}$ & 36 & 18 & 59 & 14 & 110 & 64 & 62 & 80 & 70 & 50 & 10 & 67 & 35 \\
\hline $\mathrm{Nb}$ & 17 & 17 & 28 & 11 & 24 & 16 & 10 & 10 & 10 & 14 & 10 & 16 & 13 \\
\hline $\mathrm{Y}$ & 6 & 12 & 25 & 11 & 22 & 14 & 14 & 14 & 14 & 9 & b.d.l. & 7 & 15 \\
\hline $\mathrm{Zr}$ & 120 & 120 & 150 & 118 & 180 & 120 & 131 & 144 & 119 & 110 & 117 & 100 & 136 \\
\hline $\mathrm{Ce}$ & 40 & 30 & 8 & 63 & 60 & 60 & 100 & 97 & 84 & b.d.l. & 56 & 3 & 77 \\
\hline $\mathrm{Ba}$ & 280 & 360 & 670 & 244 & 1260 & 1410 & 1518 & 1452 & 1405 & 1270 & 183 & 1450 & 651 \\
\hline $\mathrm{Sr}$ & 437 & 333 & 135 & 485 & 379 & 304 & 364 & 362 & 312 & 355 & 386 & 348 & 255 \\
\hline $\mathrm{La}$ & 20 & 40 & 80 & 30 & 30 & 40 & 30 & 30 & 30 & 20 & 30 & 40 & 30 \\
\hline ASI & 1.26 & 1.30 & 1.15 & 1.24 & 1.06 & 1.10 & 1.07 & 1.05 & 1.07 & 1.18 & 1.25 & 1.09 & 1.22 \\
\hline
\end{tabular}

The geochemical data was determined by the XRF-method at the VTT Technical Research Centre of Finland and at the Geological Survey of Finland. Data source: Talikka (2003). Oxide values wt $\%$. Others ppm. GRDR = granodiorite, TR = trondhjemite, ASI $[\mathrm{Al} /(\mathrm{Ca}-$ $1.67 \mathrm{P}+\mathrm{Na}+\mathrm{K})]=$ aluminium saturation index, b.d.l. = below detection limit.

west and steeply to the south along with the metavolcanic rocks of the TB during the Svecofennian orogeny. This is supported by slightly coarser grain size of matrix in the northern and eastern parts of the intrusion. Furthermore, the xenoliths, which formed during the emplacement as a result of magmatic stoping and commonly appear near the edges and roof of the intrusion (Pitcher, 1997), are abundant near the southern margin in the western side of the intrusion. Consequently, the current erosion level exposes a shallower level of the intrusion in the south and west and a deeper level in the north and east.

In aeromagnetic map the metavolcanic rocks of the TB show a distinct magnetic anomaly pattern with stripes of positive magnetic anomalies, and similar pattern with lower intensity is seen in the area of the Pukala intrusion (GTK Active Map explorer, http://maps.gtk.fi/gtk/eexpert.asp, map sheet 2142). This implies that the metavolcanic rocks of the TB underlie the intrusion. On the basis of the geophysi- cal and drilling data, the estimated depth of the intrusion is $1-2 \mathrm{~km}$ in the west and a bit less in the east.

\section{Hydrothermally altered rocks}

Several hydrothermally altered domains are located in the metavolcanic rocks of the TB less than one kilometre south of the Pukala intrusion. The largest of the hydrothermally altered areas, Kutemajärvi, hosts a gold deposit, which was mined (Orivesi mine) during 1994-2003 by Outokumpu Mining Oy and Polar Mining Oy. During its lifetime the mine produced 380000 ounces of gold at an average grade of $-9.1 \mathrm{~g} /$ t Au (Dragon Mining NL, 2005). Previous studies on the Kutemajärvi area include contributions from Nurmi et al. (1984), Grönholm (1992), Luukkonen et al. (1992), Luukkonen (1994), Poutiainen and Grönholm (1996), Kojonen et al. (1999), and Poutiainen et al. (1999). In addition Pihlaja (1974), Kähkönen (1989), Luodes (1989), and Papunen (1990) have 
Table 3. Geochemical data on selected Svecofennian granitoids.

\begin{tabular}{|c|c|c|c|c|c|c|c|c|c|c|c|c|c|c|c|}
\hline & \multirow{2}{*}{\multicolumn{3}{|c|}{$\begin{array}{l}\text { Pukala intrusion TR } \\
5 \text { samples }\end{array}$}} & \multirow{2}{*}{\multicolumn{3}{|c|}{$\begin{array}{l}\text { Pukala intrusion, GRDR } \\
7 \text { samples }\end{array}$}} & \multirow{2}{*}{\multicolumn{3}{|c|}{$\begin{array}{l}\text { CFGC, synkinematic } \\
127 \text { samples }\end{array}$}} & \multirow{2}{*}{\multicolumn{3}{|c|}{$\begin{array}{c}\text { CFGC, postkinematic, type } 1 \\
9 \text { samples }\end{array}$}} & \multirow{2}{*}{\multicolumn{3}{|c|}{$\begin{array}{l}\text { Rapakivi } \\
71 \text { samples }\end{array}$}} \\
\hline & & & & & & & & & & & & & & & \\
\hline & mean & $\min$ & $\max$ & mean & $\min$ & $\max$ & mean & $\min$ & $\max$ & nean & $\min$ & $\max$ & iean & $\min$ & $\max$ \\
\hline $\mathrm{O}_{2}$ & 74.9 & 73.0 & 76.4 & 72.6 & 69.5 & 75.1 & 67.7 & 56.4 & 77.2 & 66.2 & 61.5 & 72.7 & 71.4 & 65.1 & $\overline{77.0}$ \\
\hline $\mathrm{TiO}_{2}$ & 0.20 & 0.17 & 0.23 & 0.21 & 0.18 & 0.27 & 0.46 & 0.05 & 1.23 & 0.65 & 0.32 & 0.82 & 0.41 & 0.20 & 0.96 \\
\hline $\mathrm{Al}_{2} \mathrm{O}_{3}$ & 13.8 & 13.0 & 14.8 & 14.3 & 12.9 & 15.7 & 15.1 & 12.2 & 18.6 & 15.4 & 13.6 & 16.8 & 13.1 & 11.5 & 16.2 \\
\hline $\mathrm{FeOt}$ & 1.85 & 1.03 & 2.50 & 2.37 & 1.98 & 3.03 & 3.82 & 0.07 & 8.64 & 4.97 & 2.74 & 7.10 & 3.55 & 1.65 & 9.36 \\
\hline $\mathrm{MnO}$ & 95 & 0.02 & 0.07 & 0.06 & 0.04 & 08 & 0.08 & 02 & 0.18 & 0.08 & 0.05 & & 0.05 & 0.01 & 0.17 \\
\hline $\mathrm{MgO}$ & & & & & & & 4 & & & & & & & & 0.60 \\
\hline $\mathrm{CaO}$ & 15 & 1.72 & 2.43 & 1.99 & 1.69 & 2.29 & 3.08 & 0.23 & 6.69 & 2.23 & 1.38 & 2.89 & 1.45 & 0.74 & 3.17 \\
\hline $\mathrm{Na}_{2} \mathrm{O}$ & 4.96 & 4.59 & 5.59 & 3.88 & 3.47 & 4.35 & 3.48 & 2.61 & 4.53 & 2.90 & 2.71 & 3.40 & 2.70 & 1.83 & 3.23 \\
\hline $\mathrm{K}_{2} \mathrm{O}$ & 0.80 & 0.42 & 1.25 & 3.30 & 2.40 & 4.50 & 3.69 & 1.83 & 5.92 & 4.31 & 3.56 & 4.86 & 5.72 & 4.23 & 7.12 \\
\hline $\mathrm{P}_{2} \mathrm{O}_{5}$ & 0.06 & 0.04 & 0.09 & 0.07 & 0.05 & 0.11 & 0.14 & 0.01 & 0.40 & 0.27 & 0.12 & 0.36 & 0.08 & 0.01 & 0.20 \\
\hline $\mathrm{Rb}$ & 23 & 0 & 36 & 72 & 50 & 110 & 125 & 53 & 281 & 158 & 112 & 202 & 290 & 148 & 466 \\
\hline & 14 & 10 & 17 & 14 & 10 & 24 & 10 & 2 & 22 & 22 & 14 & 37 & 41 & 23 & 67 \\
\hline Y & 9 & b.d.l. & 15 & 13 & 7 & 22 & 24 & 6 & 61 & 35 & 24 & 46 & 90 & 12 & 164 \\
\hline $\mathrm{Zr}$ & 122 & 117 & 136 & 129 & 100 & 180 & 167 & 68 & 525 & 360 & 205 & 589 & 415 & 81 & 1160 \\
\hline $\mathrm{Ba}$ & 344 & 183 & 651 & 1395 & 1260 & 1518 & 781 & 203 & 1470 & 1050 & 556 & 1403 & 909 & 90 & 2090 \\
\hline $\mathrm{Sr}$ & 379 & 255 & 485 & 346 & 304 & 379 & 403 & 40 & 984 & 268 & 147 & 385 & 96 & 13 & 191 \\
\hline A/CNK & 1.07 & 1.03 & 1.10 & 1.06 & 1.02 & 1.10 & 0.99 & 0.83 & 1.11 & 1.14 & 1.01 & 1.28 & 0.99 & 0.82 & 1.22 \\
\hline
\end{tabular}

Oxide values wt $\%$. Others ppm. b.d.l. = below detection limit. $\mathrm{A} / \mathrm{CNK}=\mathrm{Al}_{2} \mathrm{O}_{3} /\left(\mathrm{CaO}+\mathrm{Na}_{2} \mathrm{O}+\mathrm{K}_{2} \mathrm{O}\right) \mathrm{mol}$.

CFGF, synkinematic (Lahtinen, unpublished). CFGF, postkinematic, type 1 (Nironen et al., 2000). Rapakivi (Vorma, 1976; Rämö, 1991).

$\mathrm{TR}=$ trondhjemite, GRDR = granodiorite, CFGC = Central Finland Granitoid Complex.

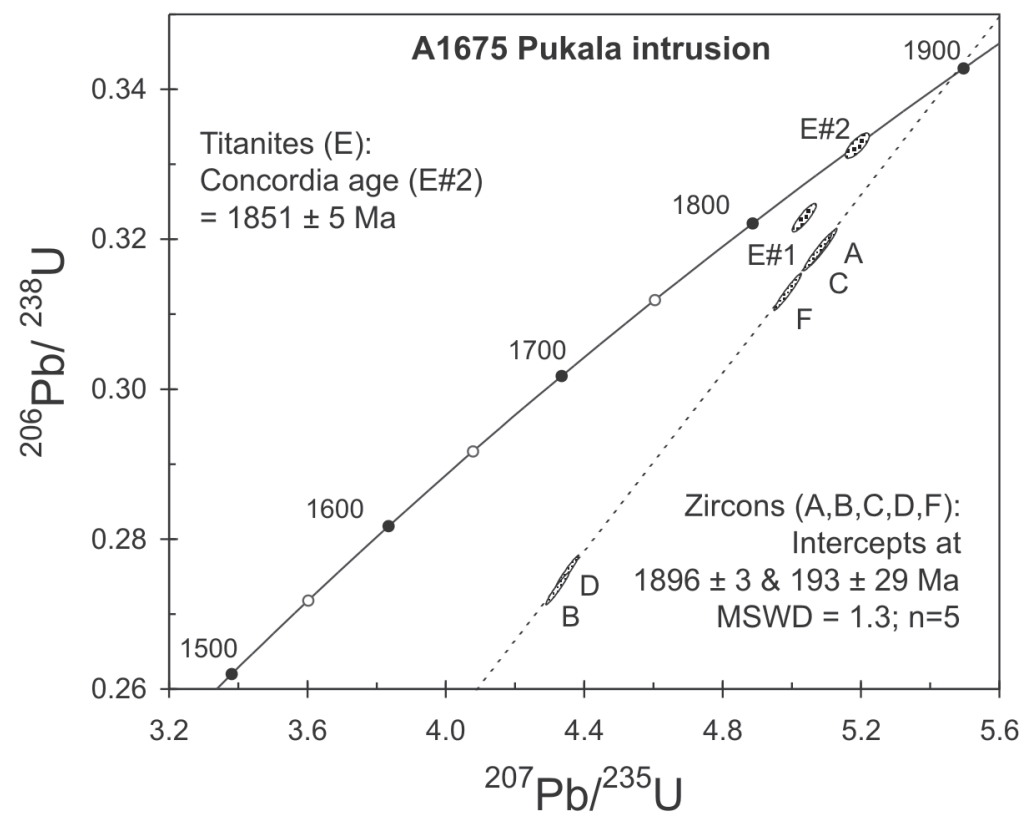

Fig. 4. Concordia plot for $\mathrm{U}-\mathrm{Pb}$ age data on zircon and titanite from sample Al675 Pukala intrusion. 


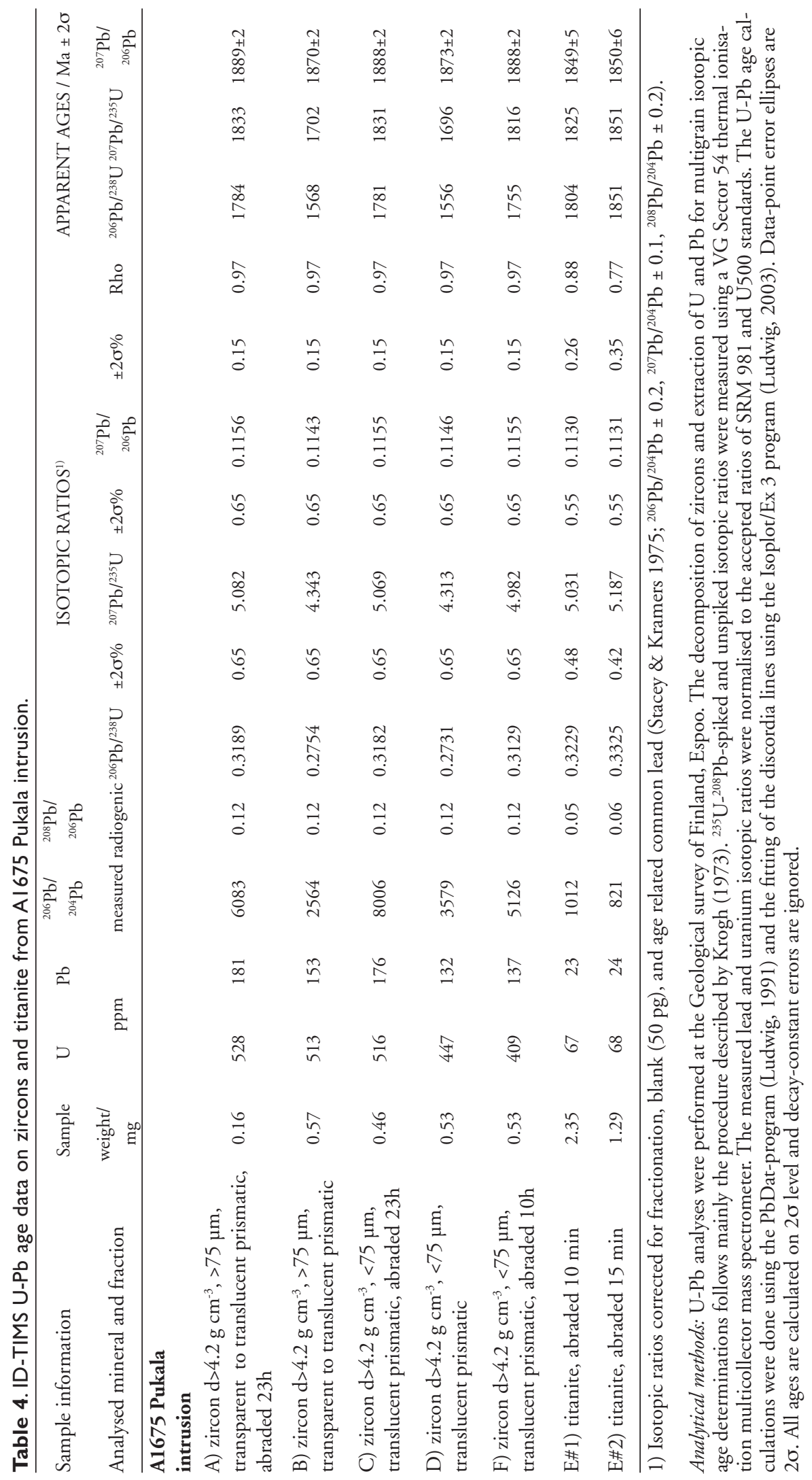


studied the metavolcanic and/or hydrothermally altered rocks in the vicinity of the Pukala intrusion.

\section{I. Main alteration types}

On the basis of field observations, the hydrothermal alteration can be divided into three basic types ( $\mathrm{Ta}-$ likka, 2003).

1. Partial silica alteration is present in the Koukkujärvi, Kutemajärvi, Iso-Teerijärvi, and Pärnävuori areas (Fig. 1). Domains of partially silicified rocks can be found in an area corresponding to the length of the Pukala intrusion. The degree of silicification varies from weak to medium and the primary structures of the metavolcanic rocks are still commonly visible. Partially silicified rocks have a sugary appearance and they lack schistosity (Fig. 2f). The main ore mineral is pyrite; other sulphides present are chalcopyrite, pyrrhotite, and galena. The amount of ore minerals increases along with the degree of silicification.

2. Chlorite-sericite \pm silica alteration exists in the Ahvenlammi, Koukkujärvi, Kutemajärvi, and Iso-Tee rijärvi areas (Fig. 1). The altered rocks commonly are foliated, pervasively altered chlorite \pm sericite schist and found as thin $(<2 \mathrm{~m})$ layers within apparently unaltered metavolcanic strata. The alteration probably proceeded along shear zones and/or permeable layers of the volcanic rocks.

At Kutemajärvi, chlorite-sericite \pm quartz schist (Fig. 2e) form the outer rim of the continuous hydrothermally altered domain and the proportion of silicification increases towards the centre of the altered area, which is dominated by sericite-quartz schist and hosts the pipe-shaped ore deposits (Grönholm, 1992). In addition, massive andalusite, quartz, and topaz rocks are present in the centre of the altered domain (Grönholm, 1992; Luukkonen, 1994). The typical ore minerals detected at Kutemajärvi are pyrite, chalcopyrite, pyrrhotite, galena, sphalerite, gold, and Te-Bi minerals (Luukkonen, 1994). Partial silica alteration of the metavolcanic rocks is found outside the halo of the chlorite-sericite schist in places.

Andalusite-muscovite breccia, which is a retrograde type of rock, exists in a limited area (pipe 3, levels $+200-+310$; pipe 5 , level $+256-490)$ in the Orivesi mine (Kutemajärvi). The brecciated appearance is due to blocks $(\varnothing 5-20 \mathrm{~cm})$ of andalusite rich material and matrix between them. The matrix is mainly composed of muscovite and pyrophyllite. Diaspore, gem-grade topaz, apatite, lazulite, and thucholite are also present in the matrix. The andalusitemuscovite breccia bodies are lens-shape (thickness 1$1.5 \mathrm{~m}$, length $-10 \mathrm{~m}$ ), subvertical (tens of meters), and without any cleavage.

3. Sericite alteration in shear zones is found in the Pärnävuori area. The subvertical, NE-trending shear zones deform partially silicified and unaltered metavolcanic rocks and the main foliation. The shearing and alteration resulted in narrow bands of sericite schist on both sides of the shears (Fig. 2f). Ore minerals are few in the sericite schist. A megabreccia structure, in which sericitised shear zones separate blocks of partially silicified and metavolcanic rocks, may exist. According to Grönholm (1992), shear zones and fold structures that deform the main foliation of the hydrothermally altered rocks and unaltered metavolcanic rocks are found at Kutemajärvi.

\subsection{Previous age constraints on Kutemajärvi al- teration}

Previous $\mathrm{U}-\mathrm{Pb}$ datings and $\mathrm{Pb}$-isotopic studies from the Kutemajärvi area have been published by Mänttäri et al. (1997). Monazite from the strongly hydrothermally altered mafic volcanic rock (chlorite schist) hosting the ore (pipe 3) has a U-Pb concordia age of $1879 \pm 2 \mathrm{Ma}$ (recalculated from previous data from Mänttäri et al., 1997). Thus, it post-dates the volcanic activity in the area. Additionally, the turbid zircons with outstandingly low ${ }^{206} \mathrm{~Pb} /{ }^{204} \mathrm{~Pb}$ ratios indicate a strong post-crystallisation hydrothermal effect at ca. $1.81 \mathrm{Ga}$.

\subsection{Comb quartz layering}

Comb quartz layers are commonly located beneath and adjacent to hydrothermal ore deposits, and associated with porphyry deposits e.g. Henderson Mo 


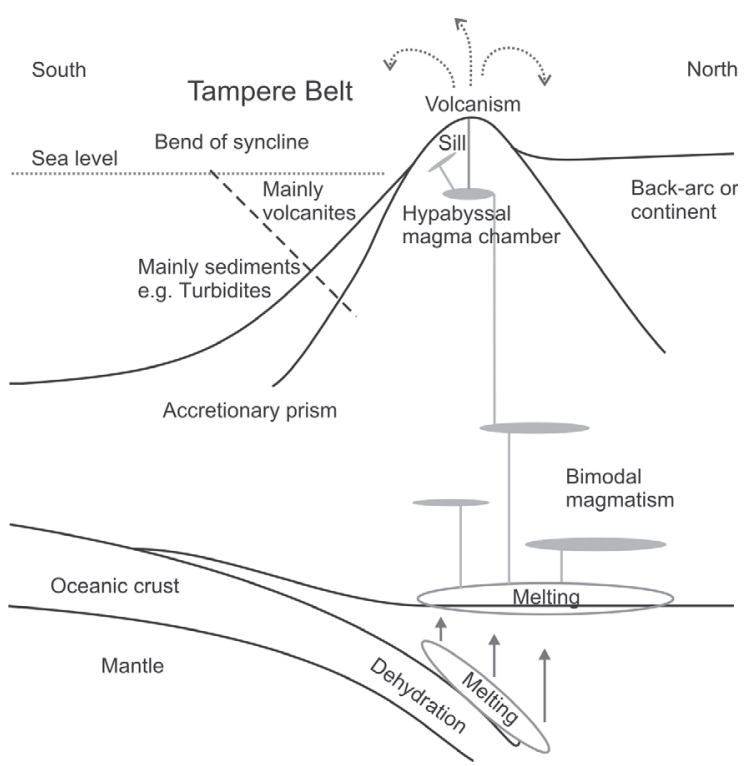

Fig. 5. Tectonic setting during the formation of the Pukala intrusion at $\sim 1.9 \mathrm{Ga}$. Oceanic crust is subducting under island-arc or active continental margin resulting to bimodal magmatism and volcanism. The Pukala intrusion represents a hypabyssal magma chamber. Modified from Talikka (2003).
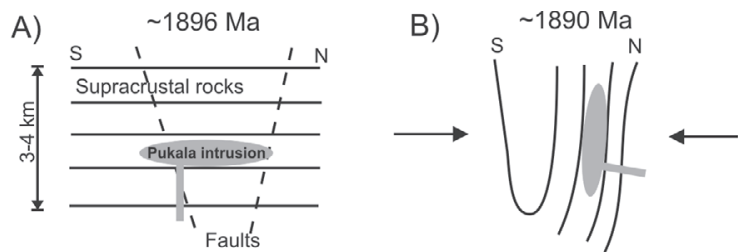

C)

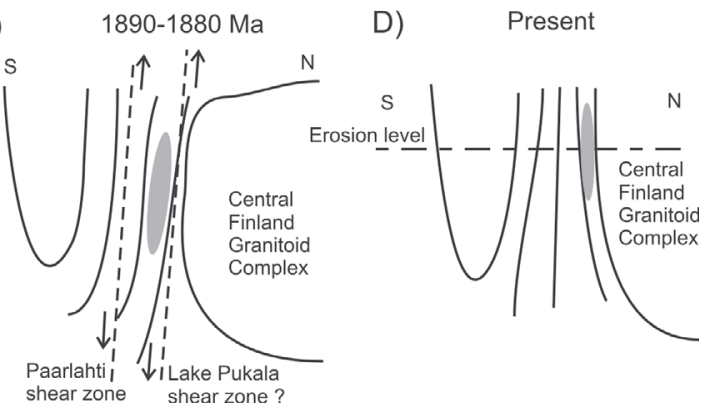

Fig. 6. Tectonic evolution of the study area during the Svecofennian orogeny. Modified from Talikka (2003).

A) Before the main regional deformation phase at $\sim 1896$ Ma. The Pukala porphyry intruded into volcanic sequence of the Tampere Belt (TB) during subduction or at the early stages of the collision between island-arcs or an island-arc and a continental margin. Shear zones may have controlled the rise of the magma to the hypabyssal levels.

B) Main regional deformation phase at $\sim 1890 \mathrm{Ma}$. Large isoclinal folds were formed during the collisional stage. The Pukala intrusion acted as a competent mass and tilted along with the adjoining volcanic rocks of the TB.

C) 1890-1880 Ma. The supracrustal rocks of the TB were deformed and metamorphosed at greenschist facies. The synkinematic granitoids of the Central Finland Granitoid Complex intruded. The formation of large shear zones.

D) Present day situation.

$\mathrm{CaO}<0.9 \%$, and $\mathrm{MgO}<0.8 \%$ (Kirkham \& Sinclair, 1988). The Pukala intrusion fits to the profile with the exception of high $\mathrm{CaO}$ (mean $2.15 \%$ ) and low $\mathrm{K}_{2} \mathrm{O}$ (mean $0.8 \%$ ) contents.

\section{Discussion}

\section{I. Geologic setting and mechanism of em- placement of the Pukala intrusion}

On the basis of the geochemical and tectonic data (Kähkönen, 1989; this study), the supracrustal rocks of the TB and the Pukala intrusion formed in an is$\mathrm{Na}_{2} \mathrm{O}>3 \%, \mathrm{~K}_{2} \mathrm{O}>4 \%, \mathrm{FeO}<2 \%, \mathrm{TiO}_{2}<0.2 \%$ 


\section{Age}

Rock type, location, geologic event

$1904 \pm 3 \mathrm{Ma}$, zircon U-Pb age of the Koskuenjärvi formation of the TB (Kähkönen et al., 1989).

Volcanism in an island-arc or fore-arc setting.

$1896 \pm 3 \mathrm{Ma}$, zircon U-Pb age of the Pukala intrusion (granodiorite).

Crystallisation of the Pukala intrusion.

$1879 \pm 2 \mathrm{Ma}$, monazite U-Pb age of the chlorite schist, Kutemajärvi (Mänttäri et al., 1997). Metamorphism after pervasive alteration.

$1851 \pm 5 \mathrm{Ma}$, titanite $\mathrm{U}-\mathrm{Pb}$ age of the Pukala intrusion (granodiorite). Regional cooling age.

$1.81 \mathrm{Ga}$, zircon Pb-Pb isochron age of the chlorite schist, Kutemajärvi (Mänttäri et al., 1997). Late hydrothermal effect.

Fig. 7. Periods of metamorphism, deformation, and hydrothermal activity linked to the age data from the study area.

land-arc or fore-arc setting (Fig. 5). The absence of carbonate rocks and iron formations and the presence of turbidites indicate a steep convergent plate margin (Kähkönen, 1999).

At hypabyssal depths, magmatic stoping is the main mechanism of intrusion (Pitcher, 1978; Holder, 1979; Pitcher, 1979). The abundant xenoliths within the Pukala intrusion are compatible with this mechanism. The large difference in viscosities between low viscosity magma and high viscosity country rocks may have caused the magma to rise along large shear zones (Pitcher, 1978; Holder, 1979; Nironen, 1985), which were formed during the early stages of the Svecofennian orogeny.

The Pukala porphyry intruded into volcanic sequence at subvolcanic depths before or during the early stages of the Svecofennian orogeny (Fig. 6), $\sim 15$ Ma before the main regional metamorphic peak at ca. $1880 \mathrm{Ma}$ (Mouri et al., 1999). The intrusion was probably a $1-2 \mathrm{~km}$ thick plate between the volcanic strata. On the basis of the stratigraphy observed today, the thickness of the volcanic rocks above the $\mathrm{Pu}$ kala intrusion $1.90 \mathrm{Ga}$ ago was $1.5-2.5 \mathrm{~km}$.

\subsection{Source and crystallisation of the Pukala in- trusion}

The Pukala intrusion shows characteristics of both Sand I-types of granitoids. The high $\mathrm{Na}$ content and the peraluminous nature point to a sedimentary ( $S$ type) source, whereas the tectonic setting and the low $\mathrm{K}$ content are typical for I-type granitoids. It is possible that the Pukala intrusion derived from both $S$ and I-type sources.

The gradual contacts between different rock types suggest either fractional crystallisation of a single magma pulse or two closely related magma pulses. The granodiorite mainly forms the interior of the intrusion and the trondhjemite is commonly found near the edges. The typical compositional rim structure due to fractional crystallisation (Pitcher, 1997) is, however, not seen in the Pukala intrusion at the current erosion level.

Using the zircon saturation thermobarometry of Watson and Harrison (1983), the crystallisation temperature of the Pukala intrusion is $760-790^{\circ} \mathrm{C}$ ( $\mathrm{Ta}$ likka, 2003). The crystallisation was probably fast, because the temperature of a small magma chamber, such as the Pukala intrusion, decreases rapidly in the middle of cool country rocks. At subvolcanic depths, the pressure of the crystallisation was low.

\subsection{Hydrothermal alteration}

The periods of hydrothermal activity can be linked to the tectonometamorphic evolution of the study area (Fig. 7). We suggest that the partial silica alteration is related to the emplacement of the Pukala intrusion and 
concomitant hydrothermal activity and contact metamorphism at ca. $1.90 \mathrm{Ga}$. This hypothesis is supported by the presence of several partially silicified domains in the vicinity of the southern margin of the Pukala intrusion along its whole length. Furthermore, the partial silica alteration is commonly present in the same areas (Iso-Teerijärvi, Koukkujärvi, and Kutemajärvi) as the chlorite-sericite \pm silica alteration.

Pervasive chlorite-sericite \pm silica alteration requires an extensive hydrothermal system and probably took place at epithermal depths $(1.5-2.5 \mathrm{~km})$ at ca. 1.90 $\mathrm{Ga}$, before or during the main regional deformation phase, which occurred at ca. 1.89 Ga (Nironen 1989; Kilpeläinen, 1998). The monazite U-Pb age of 1.88 $\mathrm{Ga}$ from the ore related chlorite schist (Mänttäri et al., 1997) supports the timing of the alteration. The intense sericitisation, formation of quartz ( \pm aluminium bearing) rocks and the comb quartz bands in the contact of the altered domain at Kutemajärvi and the Pukala intrusion indicate that the hydrothermal fluids were acid and probably had a magmatic origin. The small crustal component in the Pb-isotopic composition of galena, its model age (1888 Ma), and occurrence in the chlorite schist at Kutemajärvi also points to a plutonic source for the fluids (Mänttäri et al., 1997).

The sericitised shear zones may have formed when competent, partially silicified rocks were sheared and resulted in a large-scale megabreccia structure during the late stages, -1.85 (titanite of the Pukala intrusion)-1.81 (turbid zircons at Kutemajärvi) Ga, of the regional deformation.

\section{Summary and conclusions}

The Pukala intrusion formed in an island-arc or forearc setting during the early stages of the Svecofennian orogeny. The porphyry intruded into the volcanic sequence of the Tampere Belt, resulting in a sheetshaped pluton. The mechanism of the emplacement was magmatic stoping, which is evidenced by the abundant xenoliths.

The two main rock types of the intrusion are porphyritic granodiorite and trondhjemite; these types can be distinguished by geochemistry, petrology, and lithology. The contacts between the granodiorite and trondhjemite are gradual. During the Svecofennian orogeny, the intrusion is tilted gently towards east and steeply towards south.

The zircon $\mathrm{U}-\mathrm{Pb}$ age for the Pukala intrusion is $1896 \pm 3 \mathrm{Ma}$, and the titanite age of $1851 \pm 5 \mathrm{Ma}$ may indicate the waning stages of the Svecofennian tectonometamorphic evolution of the region. On the basis of the geochemical data, the Pukala intrusion is a volcanic arc granitoid. The magma has predominantly derived from a crustal source, although some of the trondhjemite samples show characteristics of mantle fractionates.

The Pukala intrusion was the dynamo of the hydrothermal system that resulted in the small altered domains in its country rocks to the south. This is supported by the mineral assemblages produced by alteration, geometry of the altered areas, lead isotope composition, and the presence of the comb quartz bands in the contact of the Pukala intrusion and the altered domain at Kutemajärvi.

\section{Acknowledgements}

The authors thank the geological staff, Pentti Grönholm, Aulis Kinnunen, Risto Pietilä, Aatto Ratia, and Heikki Saarnio, of the Outokumpu Mining Oy / Orivesi mine and Exploration for their cooperation and financial support. We thank journal reviewers Dr. Pasi Eilu and Dr. Mikko Nironen and editor-in-chief Dr. Petri Peltonen for constructive comments that led to improvements of the manuscript. The comments of Emer. Prof. Ilmari Haapala and Prof. Tapani Rämö (University of Helsinki), as well as helpful discussions with colleagues, are acknowledged. Dr. Raimo Lahtinen (Geological Survey of Finland) is thanked for the unpublished data he provided the authors with. Furthermore, M. Karhunen, L. Järvinen, and M. Niemelä are thanked for rock crushing, mineral separation, and laboratory assistance. 


\section{References}

Batchelor, R. \& Bowden, P., 1985. Petrologic interpretation of granitoid rock series using multicationic parameters. Chemical Geology 48, 43-55.

Gaál, G. \& Gorbatschev, R., 1987. An outline of the Precambrian evolution of the Baltic Shield. Precambrian research 35, 15-52.

Grönholm, P., 1992. Oriveden Kutemajärven kultaesiintymän ja sen ympäristön geologia. M.Sc. Thesis, University of Helsinki, 115 p.

Dragon Mining NL, 2005. Press release 24 February 2005. http://www.dragon-mining.com.au/pages/ASX/2005/ 24feb2005_vammala_production_centre.htm

Heald, P., Foley, N.K. \& Hayba, D.O., 1987. Comparative Anatomy of Volcanic-Hosted Epithermal Deposits: Acid-Sulfate and Adularia-Sericite Types. Economic Geology $82,1-26$.

Hedenquist, J.W., Izawa, E., Arribas, A. \& White, N.C., 1996. Epithermal gold deposits: Styles, characteristics, and exploration. Resource Geology Special Publication $1,16 \mathrm{p}$.

Holder, M.T., 1979. An emplacement mechanism for posttectonic granites and its implications for their geochemical features. In: Atherton, M.P. \& Tarney, J. (eds.) Origin of Granite Batholiths: Geochemical Evidence. Shiva, Orpington, 116-128.

Hölttä, P., 1986. Observations on the metamorphic reactions and PT conditions in the Turku granulite area. In: Korsman, K. (ed.) Development of deformation, metamorphism and metamorphic blocks in eastern and southern Finland. Geological Survey of Finland, Bulletin 339, 43-58.

Huhma, H., 1986. Sm-Nd, U-Pb and Pb-Pb isotopic evidence for the origin of the Early Proterozoic Svecokarelian crust in Finland. Geological Survey of Finland, Bulletin 337, 48 p.

Kähkönen, Y., 1989. Geochemistry and petrology of the metavolcanic rocks of the early Proterozoic Tampere Schist Belt, southern Finland. Geological Survey of Finland, Bulletin 345, 104 p.

Kähkönen, Y., Huhma, H. \& Aro, K., 1989. U-Pb zircon ages and $\mathrm{Rb}-\mathrm{Sr}$ whole rock isotope studies of early Proterozoic volcanic and plutonic rocks near Tampere, southern Finland. Precambrian Research 45, 27-43.

Kähkönen, Y., 1999. Stratigraphy of the central parts of the Paleoproterozoic Tampere Schist Belt, southern Finland: review and revision. Bulletin of the Geological Society of Finland 71, 13-29.

Kilpeläinen, T., 1998. Evolution and 3D modelling of structural and metamorphic patterns of the Palaeoproterozoic crust in the Tampere-Vammala area, southern Finland. Geological Survey of Finland, Bulletin 397, 124 p.

Kirkham, R.V. \& Sinclair, W.D., 1988. Comb quartz layers in felsic intrusions and their relationship to porphyry deposits. In: Recent Advances in the Geology of Granite-Related Mineral Deposits. The Canadian Institute of
Mining and Metallurgy, Special Volume 39, 50-71.

Kojonen, K., Sorjonen-Ward, P., Saarnio, H. \& Himmi, M., 1999. The early Proterozoic Kutema gold deposit, Southern Finland. In: Stanley et al. (eds.) Mineral Deposits: Processes to Processing. Proceedings of the Fifth Biennal SGA Meeting and 10. IAGOD Quadrennial Symposium, London, 22-25.9.1999. 177-180.

Korsman, K., 1977. Progressive metamorphism of the metapelites in the Rantasalmi-Sulkava area, southeastern Finland. Geological Survey of Finland, Bulletin 290, 82 p.

Korsman, K., Hölttä, P., Hautala, T. \& Wasenius, P., 1984. Metamorphism as an indicator of evolution and structure of the crust in eastern Finland. Geological Survey of Finland, Bulletin 328, 40 p.

Korsman, K., Koistinen, T., Kohonen, J., Wennerström, M., Ekdahl, E., Honkamo, M., Idman, H. \& Pekkala, Y., (eds.) 1997. Suomen kallioperäkartta - Berggrundskarta över Finland - Bedrock Map of Finland. 1:1 000 000. Geological Survey of Finland, Espoo.

Krogh, T.E., 1973. A low-contamination method for hydrothermal decomposition of $\mathrm{U}$ and $\mathrm{Pb}$ for isotopic age determinations. Geochimica et Cosmochimica Acta 37, 485-494.

Lahtinen, R., Korja, A. \& Nironen, M., 2005. Paleoproterozoic tectonic evolution of the Fennoscandian Shield a plate tectonic model. In: Lehtinen, M., Nurmi, P. \& Rämö, O.T. (eds.) Precambrian Geology of Finland Key to the Evolution of the Fennoscandia Shield. Elsevier Science B.V., Amsterdam, 483-504.

Laitakari, I., 1986. Orivesi. Geological map of Finland 1:100 000, pre-Quaternary rocks, sheet 2142, Geological Survey of Finland.

Laitakari, I., 1987. Hämeen subjotuninen juoniparvi - The subjotunian dyke swarm of Häme. In: Aro, K. \& Laitakari, I. (eds.) Suomen diabaasit ja muut mafiset juonikivilajit. Geological Survey of Finland, Report of Investigation 76, 99-116.

Ludwig, K.R., 1991. PbDat 1.21 for MS-dos: A computer program for IBM-PC Compatibles for processing raw $\mathrm{Pb}-\mathrm{U}-\mathrm{Th}$ isotope data, Version 1.07.

Ludwig, K.R., 2003. Isoplot/Ex 3. A geochronological toolkit for Microsoft Excel. Berkeley Geochronology Center, Special publication 4.

Luodes, H., 1989. Oriveden Ison Teerijärven hydrotermisesti muuttuneet vulkaniitit. M.Sc Thesis, University of Turku, $81 \mathrm{p}$.

Luukkonen, A., Grönholm, P. \& Hannila, T., 1992. Eräiden Etelä-Suomen kulta- ja sen seuralaismetalliesiintymien geologiset pääpiirteet. Summary: Main geological features of certain gold and tungsten-tin-gold prospects in Southern Finland. Geological Survey of Finland, Report of Investigations 113, $90 \mathrm{p}$.

Luukkonen, A., 1994. Main geological features, metallogeny and hydrothermal alteration phenomena of certain gold and gold-tin-tungsten prospects in southern Finland. Geological Survey of Finland, Bulletin 377, 153 p. 
Mänttäri, I., Luukkonen, A. \& Grönholm, P., 1997. Isotopic studies on the Kutemajärvi gold deposit, Orivesi, Southern Finland. In: S. Autio (ed.) Geological Survey of Finland, Current Research 1995-1996. Geological Survey of Finland, Special Paper 23, 55-58.

Mouri, H., Korsman, K. \& Huhma, H., 1999. Tectonometamorphic evolution and timing of the melting processes in the Svecofennian Tonalite-Trondhjemite Migmatite Belt: An example from Luopioinen, Tampere Area, southern Finland. Bulletin of the Geological Society of Finland 71, 31-56.

Nironen, M., 1985. Eräiden svekokarjalaisten granitoidien intruusiomekanismit ja tektoninen asema sekä niihin liittyvien porfyyrityyppisten Mo- ja Cu-esiintymien rakenne. Ph.Lic. Thesis, University of Finland, Finland, $97 \mathrm{p}$.

Nironen, M., 1989. Emplacement and structural setting of granitoids in the early Proterozoic Tampere and Savo Schist Belts, Finland - implications for contrasting crustal evolution. Geological Survey of Finland, Bulletin 346, 83 p.

Nironen, M., 1997. The Svecofennian orogen: a tectonic model. Precambrian Research 86, 21-44.

Nironen, M., Elliot, B. \& Rämö, O.T., 2000. 1.88-1.87 Ga post-kinematic intrusions of Central Finland Granitoid Complex: a shift from C-type to A-type magmatism during lithospheric convergence. Lithos 53, 37-58.

Nironen, M., Lahtinen, R. \& Koistinen, T., 2002. Suomen geologiset aluenimet - yhtenäisempään nimikäytäntöön!. Summary: Subdivision of Finnish bedrock - an attempt to harmonize terminology. Geologi 54, 8-14.

Nurmi, P.A., Front. K., Lampio, E. \& Nironen, M., 1984 Etelä-Suomen svekokarjalaiset porfyyrityyppiset molybdeeni- ja kupariesiintymät, niiden granitoidi-isäntäkivet ja litogeokemiallinen etsintä. Svecokarelian porphyrytype molybdenum and copper occurrences in southern Finland: their granitoid host rocks and lithogeochemical exploration. Geological Survey of Finland, Report of Investigations 67, 88 p.

Nurmi, P. \& Haapala, I., 1986. The Proterozoic granitoids of Finland: Granite types, metallogeny and relations to crustal evolution. Bulletin of the Geological Society of Finland 58, 203-233.

Papunen, H. (ed.) 1990. Sinkkiprojektin loppuraportti. University of Turku, Institute of Geology and Mineralogy, Publication 22, 143 p.

Pearce, J.A., Harris, N.B.W. \& Tindle, A.G., 1984. Trace element discrimination diagrams for the tectonic interpretation of granitic rocks. Journal of Petrology 25, 956-983.

Pesonen, L.J. \& Neuvonen, K.J., 1981. Paleomagnetism of the Baltic Shield - Implications for Precambrian tectonics. In: Kröner, A. (ed.) Precambrian Plate Tectonics. Elsevier, Amsterdam, 623-648.

Pihlaja, P., 1974. Oriveden vulkaniiteista. M.Sc. Thesis, University of Turku, $78 \mathrm{p}$.

Pitcher, W.S., 1978. The anatomy of batholith. Journal of
Geological Society of London 135, 157-182.

Pitcher, W.S., 1979. The nature, ascent and emplacement of granitic magmas. Journal of Geological Society of London 136, 627-662.

Pitcher, W.S., 1997. The nature and origin of granite. Chapman \& Hall, London, 387 p.

Poutiainen, M. \& Grönholm, P., 1996. Hydrothermal fluid evolution of the Paleoproterozoic Kutemajärvi goldtelluride deposits, SW Finland. Economic Geology 91, 1335-1353.

Poutiainen, M., Ristolainen, J., Grönholm, P. \& Luukkonen, A., 1999. Retrograde metamorphic $\mathrm{H}_{2} \mathrm{O}-\mathrm{NaCl}-$ $\mathrm{CO}_{2}-\mathrm{CH}_{4}-\mathrm{N}_{2}$ fluid inclusions in orogenic lode-gold deposits of the Paleoproterozoic volcanic-sedimentary Tampere Schist Belt (TSB), southern Finland. In: Cook, N.J. \& Sundblad (eds.) Precambrian gold in the Fennoscandian and Ukrainian Shields and related areas. Gold '99 Trondheim, Norway, 4-6 May 1999. Geological Survey of Norway, Trondheim, 129-130.

Rämö, O.T., 1991. Petrogenesis of the Proterozoic rapakivi granites and related basic rocks of southeastern Fennoscandia: $\mathrm{Nd}$ and $\mathrm{Pb}$ isotopic and general geochemical constraints. Geological Survey of Finland, Bulletin 355, $161 \mathrm{p}$.

Schreurs, J., 1984. The amphibolite-granulite facies transition in West Uusimaa, S.W. Finland. A fluid inclusion study. Journal of Metamorphic Geology 2, 327-341.

Schreurs, J. \& Westra, L., 1985. Cordierite-orthopyroxene rocks: the granulite facies equivalents of the Orijärvi cordierite-antophyllite rocks in West Uusimaa, southwest Finland. Lithos 18, 215-228.

Seitsaari, J., 1951. The Tampere schist belt northeast of Tampere in Finland. Bulletin de la Commission Geologique de Finlande 153, 120 p.

Stacey, J.S. \& Kramers, J.D., 1975. Approximation of terrestrial lead isotope evolution by a two-stage model. Earth and Planetary Science Letters, 26, 207-221.

Streckeisen, A.L., 1974. Classification and nomenclature of igneous rocks. Geologische Rundschau, 63, 773-786.

Talikka, M., 2003. Pukalan porfyyri ja sen yhteys hydrotermiseen muuttumiseen Orivedellä. M.Sc. Thesis, University of Helsinki, Finland, 119 p.

Vorma, A., 1976. On the petrochemistry of rapakivi granites with special reference to the Laitila massif, southwestern Finland. Geological Survey of Finland, Bulletin $28598 \mathrm{p}$.

Watson, E.B. \& Harrison, T.M., 1983. Zircon saturation revisited: temperature and composition effects in a variety of crustal magma types. Earth Planetary Science Letters 64, 295-304.

Whalen, J.B., Currie, K.L. \& Chappel, B.W., 1987. A-type granites: geochemical characteristics, discrimination and petrogenesis. Contribution to Mineralogy and Petrology $95,407-419$. 
